\title{
The role of science and advocacy in the conservation of Southern Ocean albatrosses at
}

sea

JOHN P. CROXALL

\begin{abstract}
Summary
Mortality of albatrosses (and petrels) as bycatch in longline fisheries is one of the most important and pervasive sources of mortality for many species and is often closely linked to observed population declines. In the area of the Southern Ocean managed by the Commission for the Conservation of Antarctic Marine Living Resources (CCAMLR), which includes the waters around South Georgia, Prince Edward Islands, Iles Crozet and Kerguelen (the most important sub-Antarctic breeding sites for many albatross - and petrel - species), such bycatch was reduced to negligible levels (in demographic terms) over the last decade. The process by which this was achieved, in terms of data, policy and practice, together with an assessment of the main drivers and obstacles, is described. The extent to which the CCAMLR example is a model for other Regional Fisheries Management Organisations (RFMOs) (and even for states with jurisdiction in relevant coastal waters) is assessed. Some current actions and priorities for further action in relation to seabird bycatch are summarised.
\end{abstract}

\section{Introduction}

It has long been recognised that effective conservation and management of marine habitats is many times more difficult than in terrestrial systems. This is particularly true of areas outside national jurisdiction, especially the high seas. Contributing factors to this include the widespread perception that marine resources and systems are inexhaustible, jurisdictional difficulties, lack of effective management and responsibility, lack of data (except on a few harvested species) and lack of understanding of system interactions, especially how effects at one trophic level influence species and habitats at other levels.

For these and related reasons, successful conservation and management initiatives in marine systems are scarce, even at the (small) scales at which total habitat protection is potentially feasible. In most cases, progress to minimise adverse impacts, whether relating to exploitation or pollution, needs to involve negotiation not just with relevant jurisdictional rights holders but also with organisations directly involved in the exploitation or pollution, usually operating within a variety of legal (and sometimes illegal) frameworks. One marine conservation initiative that appears to have enjoyed considerable success (so far!) involves minimising the bycatch of albatrosses and petrels associated with fishing, particularly on the high seas in the Southern Ocean. It may be instructive, therefore, to examine how this success was achieved and especially the iterative interaction between scientific data (both ad hoc and from designed studies), advocacy and management action, all of which were essential to making progress. It is also important to indicate some of the steps necessary to consolidate and make further progress and to assess the extent to which the advances achieved within the CCAMLR area might be replicated in areas under other jurisdictions. 


\section{Background and context}

Long-term studies of albatross populations have been undertaken at a number of Southern Hemisphere breeding sites. Foremost amongst these, in terms of scope, scale, continuity and consistency, were those at South Georgia and Iles Crozet (Croxall et al. 1990, Jouventin and Weimerskirch 1990, Prince et al. 1994, Weimerskirch et al. 1997). Decreases in the study populations of several species became evident in mid-1980s, starting an evaluation of what factors might be responsible. Given that albatrosses are extensively dependent on marine prey and spend most of their life at sea, considering potential influences in the marine environment was obviously important. This promoted analysis of ringing recoveries away from the breeding sites and consideration of interactions with Southern Ocean fisheries, especially those in the vicinity of the breeding sites. By the mid-1980s, the management of fisheries in the Southern Ocean, including around South Georgia and Iles Crozet (and also other key albatross breeding sites such as the Prince Edward Islands) had become the responsibility of a new international agreement, the Commission for the Conservation of Antarctic Marine Living Resources (CCAMLR). This had been developed primarily because of increasing concern over the history (and future) of unregulated harvesting in the region.

Thus commercial harvesting of Antarctic marine living resources had followed a familiar pattern of prospecting, exploitation and over-exploitation (Croxall and Nicol 2004; Kock et al. 2007). By the late 1970s, just two centuries after the discovery of the region's resources, most, if not all, populations of Antarctic Fur Seal Arctocephalus gazella, several species of great whales and Marbled Rock Cod Notothenia rossii were commercially unviable and nearly biologically extinct. Fisheries were switching to Antarctic Icefish Champsocephalus gunnari (already overexploited by 1980) and Antarctic Krill Euphausia superba. There was an overriding fear that not only would recently protected whale populations fail to recover, but that many other species dependent on krill would be affected by its harvesting.

Therefore, in 1977, the contracting parties to the Antarctic Treaty, which had been successful in depoliticising governance (territorial claims) and promoting scientific collaboration in respect of the Antarctic Continent, started to negotiate an international convention, primarily to prevent over-exploitation of marine resources, especially Antarctic Krill. The resulting CCAMLR Convention, signed in 1980 and in force since 1982, applies to the whole Southern Ocean south of the Antarctic Polar Front - an area of 32 million $\mathrm{km}^{2}$. The marine living resources involved in the Convention include all species in the Convention Area other than whales and seals, for which there were existing Conventions. The CCAMLR Convention was the first in the marine environment to try to combine the requirements of sustainable harvesting with adequate protection for non-target species potentially affected by harvesting. In fact, in three of its fundamental principles, it was foreshadowing, by at least a decade, the widespread adoption of the precautionary principle and the need for ecosystem-based approaches to the management of marine systems. Thus, Article II of the CCAMLR Convention contains the requirements:

1. to balance the needs of sustainable harvesting with those of conservation;

2. to provide protection for dependent and related species, coupled with the restoration of depleted stocks and populations; and

3. to avoid changes that are potentially irreversible within 2 to 3 decades.

It was in this context that the analysis and presentation of scientific data and consideration of how to address the problems identified, took place.

\section{Actions and outcomes}

\section{The initial scientific data}

The main stimulus to commencing advocacy, initially to CCAMLR and in respect of the situation at South Georgia (by far the best documented at that time), derived from the availability of four sets of data, summarised below. 
Change in albatross populations

The most recent portrayal of trends in the Bird Island, South Georgia populations of Wandering, Grey-headed and Black-browed Albatrosses (Diomedea exulans, Thalassarche chrysostoma and T. melanophrys) is shown in Fig. 1. This also serves to illustrate the situation prevailing in the mid-to-late 1980 s when the data were being first analysed to assess population trends. The strength of these data was that the time series comprised information from an annual capturemark-recapture study of large numbers of individuals of each of three species in each year from 1972 onwards. Comparison with population counts from 1958-1963 was also available. In addition, Bird Island colonies not used for the detailed population studies were counted at 5-year intervals to provide control data. Some information was also available for colonies of these species elsewhere on South Georgia and a systematic resurvey of these was eventually undertaken. Despite the complications created by deferred breeding and by the quite substantial inter-annual variation, especially in the two biennial-breeding species (Wandering and Greyheaded Albatrosses), whereby alternating demi-populations exist (because early failing birds breed again the next year), the published analyses (Croxall et al. 1990, Prince et al. 1994) provided ample evidence of statistically significant population decrease. These results were

(a)

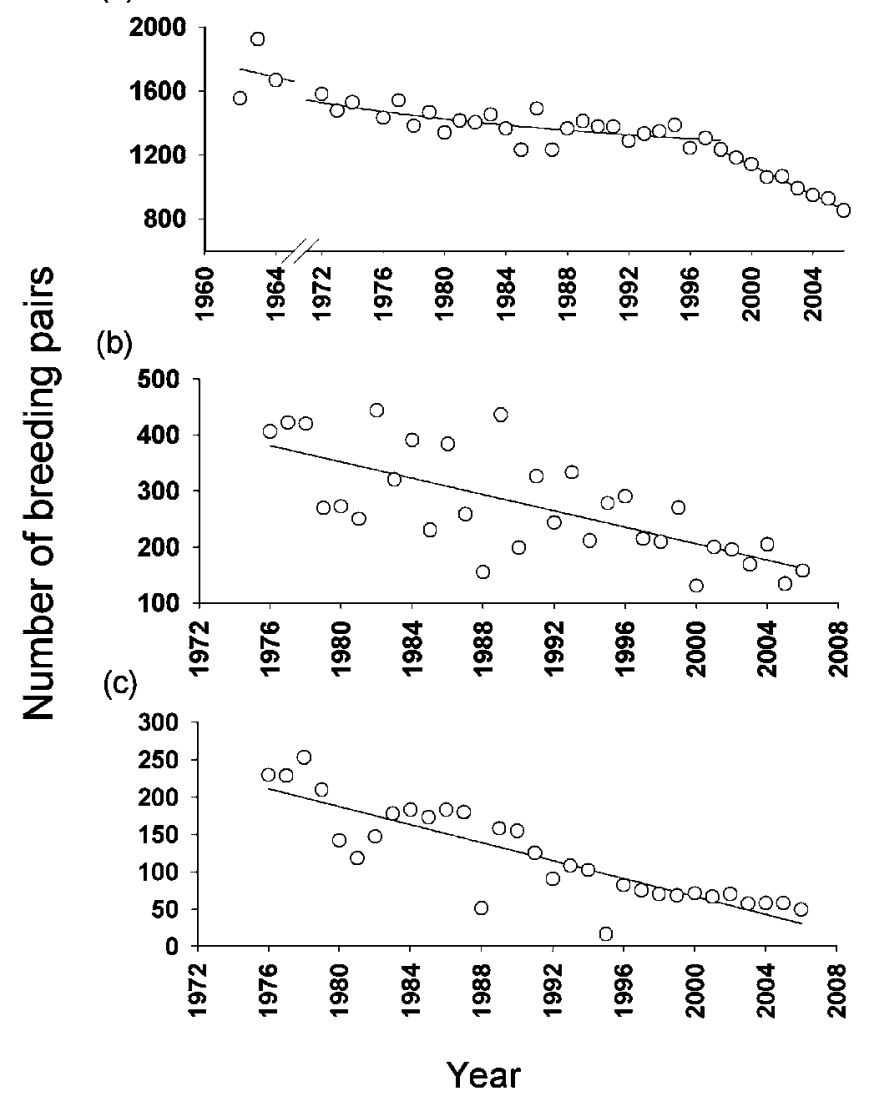

Figure 1. Changes in population size of albatrosses in study colonies at Bird Island, South Georgia (British Antarctic Survey unpublished data); (a) Wandering Albatross (whole island counts), (b) Grey-headed Albatross (Colony E) and (c) Black-browed Albatross (Colony H). 
Table 1 . Differences in survival rates and annual rate of change of breeding populations of South Georgia albatrosses to 1998. Values are percentages. (From Croxall et al. 1998).

\begin{tabular}{|c|c|c|c|c|c|c|c|c|}
\hline \multirow[t]{2}{*}{ Species } & \multicolumn{2}{|c|}{ Adult Survival } & \multicolumn{2}{|c|}{ Breeding success } & \multicolumn{2}{|c|}{ Recruitment rate } & \multicolumn{2}{|c|}{ Population change } \\
\hline & Then & Now & Then & Now & Then & Now & Then & Now \\
\hline $\begin{array}{l}\text { Wandering } \\
\text { Albatross }{ }^{1}\end{array}$ & 96 & 92 & 60 & 70 & 36 & 27 & o & -1.0 \\
\hline $\begin{array}{l}\text { Grey-headed } \\
\text { Albatross }^{2}\end{array}$ & $(95)^{3}$ & 93 & 40 & 39 & 36 & C. 5 & o & -1.4 \\
\hline $\begin{array}{l}\text { Black-browed } \\
\text { Albatross }^{2}\end{array}$ & 93 & 89 & 36 & 18 & 27 & c. 7 & +0.5 & -6.9 \\
\hline
\end{tabular}

${ }^{1}$ Then: pre-1970; Now: since 1987. ${ }^{2}$ Then: 1970s; Now: since 1987. ${ }^{3}$ Estimated value.

supported by later analyses (Croxall et al. 1998, Tuck et al. 2001, 2004, Arnold et al. 2006) and by data from other sites at Bird Island and South Georgia (Poncet et al. 2006).

In addition, it was possible to investigate relationships between productivity, fecundity and survival to show clearly which components of the population were most affected. These results are summarised in Table 1 . They show different balances between different species (unsurprising considering later discoveries concerning foraging ranges at different stages of breeding and life cycles) but indicate that a significant reduction in both adult survival and juvenile survival (recruitment) had occurred in all species. These data also showed that the former was likely to be the main driver of the population change because albatross populations are about five times more sensitive to changes in adult, than juvenile, survival (Croxall and Rothery 1991). In Wandering Albatross there had been least effect on juvenile survival and recruitment and adult survival was significantly female-biased (again, of particular significance for the breeding population). The absence of land-based predators, the consistently high levels of breeding success in Wandering Albatross, the lack of significant change across time in breeding frequency and breeding success in all species and the relative insensitivity of albatross populations to changes in these variables, all suggested that the main causes of the population changes needed to be sought at sea and were as likely (or more so, depending on species) to involve events outside the chick-rearing season (which lasts some 3-6 months in albatrosses, depending on species). This focused attention on the few data available at the time on albatross distribution, abundance and mortality at sea.

\section{Recoveries and causes of death of ringed birds}

In the mid-1980s, the only species with sufficient data for analysis was the Wandering Albatross (Croxall and Prince 1990). Even though 20,000 Wandering Albatrosses had been ringed over 29 years at Bird Island, South Georgia, only 81 recoveries had been reported (0.4\%). This small sample precluded complex analysis; in most cases splitting the sample into two equivalent time periods (1960-74 and 1975-88) that corresponded to before and after the start of commercial longline fishing, was the most that could be done. Nevertheless, the main results of comparing the likely causes of death in these two periods, summarised in Table 2, were reasonably clear-cut. First, recovery rates and proportions of juveniles and adults had not changed substantially over time. Second, most recoveries in the first period came from Australasia, in the second period from South America. Third, the proportion of birds caught in association with fishing increased from $38 \%$ to $63 \%$. Three-quarters of the latter were killed on longlines set (i.e. deployed) for tuna, a circumstance not mentioned in recoveries prior to 1978. Fourth, birds killed due to longline fishing were mainly adults and disproportionately female. These results matched very well, in general, the findings of the population studies.

The strength of these data was their unequivocal evidence of South Georgia Wandering Albatrosses being killed due to longline fishing (the birds are attracted to the baited hooks, pulled 
Table 2. Regions and circumstances of recoveries (number of birds) of Wandering Albatrosses ringed at Bird Island, South Georgia, 1958-1986 (modified from Croxall and Prince 1990).

\begin{tabular}{|c|c|c|c|c|c|c|c|c|}
\hline & \multicolumn{4}{|c|}{$1960-1974$} & \multicolumn{4}{|c|}{$1975-1988$} \\
\hline & $\begin{array}{l}\text { South } \\
\text { America }\end{array}$ & Australasia & Other & Total & $\begin{array}{l}\text { South } \\
\text { America }\end{array}$ & Australasia & Other & Total \\
\hline \multicolumn{9}{|l|}{ Fishery } \\
\hline Longline & $\mathrm{O}$ & o & o & $\mathrm{O}$ & 14 & 1 & 1 & 16 \\
\hline Other & 5 & 3 & 3 & 11 & 5 & $\mathrm{o}$ & o & 5 \\
\hline At sea & 4 & 9 & 5 & 18 & 1 & 3 & 8 & 12 \\
\hline Ashore & $\mathrm{O}$ & 5 & 1 & 6 & 7 & 6 & o & 13 \\
\hline
\end{tabular}

under and drowned), that adults (and females) were disproportionately represented and that these events represented a substantial change in causes of reported mortality during the second half of the study period, coinciding with the development of longline fishing. The weakness of the data, apart from the inherent potential biases associated with recovery data in general and from at-sea sources in particular, were the small samples deriving from a single breeding site of one species.

\section{Direct observations of interactions between albatrosses and longline fisheries}

At the time of the two studies above, there were no published direct observations by scientists or fishery observers of bycatch mortality of albatrosses in longline fisheries. However, similar concerns for Tasmanian Shy Albatrosses Thalassarche cauta had stimulated Brothers (1991) to obtain albatross bycatch data from several vessels using longlines to catch Southern Bluefin Tuna Thunnus maccoyii off Tasmania in May-June 1988. The total sample of hooks observed was 108,662 and 45 albatrosses were observed or reported caught, an average rate of 0.41 birds per 1,000 hooks, generating an overall estimate for the whole Southern Bluefin Tuna fishery in the Southern Ocean of 44,00o albatrosses killed annually.

The strength of this study was the first unequivocal quantified observations of rates and levels of bycatch for albatrosses and petrels associated with a commercial longline fishery for tuna. The weaknesses were that the data derived from a small number of vessels in a single fishery and fishing area and covered a relatively short period of the year. Concerns were subsequently expressed over the nature of the extrapolation, with more rigorous analysis yielding a lower estimate of about 39,000 albatrosses per annum (Brothers et al. 1998, Klaer and Polacheck 1998). However, all estimates based on birds reported or observed brought dead on board are clearly substantial under-estimates, because many birds killed at the set do not remain on the hooks when the lines come on board.

The fourth piece of evidence was observations of three hauls from sets of longlines by two vessels targeting Patagonian Toothfish Dissostichus eleginoides in the vicinity of South Georgia in 1991 (Dalziell and De Poorter 1993). They recorded a minimum mortality of six birds (two albatrosses, four petrels) and concluded that, if these vessels and circumstances were typical of the rest of the fishery, some 3,500 petrels (including more than 1,000 albatrosses) would be killed annually in the Patagonian Toothfish longline fishery around South Georgia. The obvious weaknesses of these data were the very limited observations for quite a substantial extrapolation!

\section{The initial management authority response}

Although CCAMLR had requested reports on incidental mortality since 1986, none had been forthcoming and, with the advent of longline fishing in the Convention Area (at South Georgia) in 1989, the information on potential causes of the observed population declines was sufficient 
for incidental mortality to become a specific agenda item for the Scientific Committee and for data forms for reporting incidental mortality to be developed by the Scientific Committee's Working Group on Fish Stock Assessment in 1990.

At the 1991 CCAMLR meetings, all the information described above was available for the first time. Although there was a considerable diversity of views amongst the 24 Member States of CCAMLR as to the severity of the problem and the nature of any management action, it was agreed that it was incumbent on CCAMLR to make some response. This reflected the recognition that:

(a) population decreases of albatrosses breeding within the Convention Area were demonstrably of a magnitude irreversible within $2-3$ decades, particularly if the fishery-related interactions suggested to be influencing these were not addressed in some way;

(b) although the evidence presented on causes of the decline was largely circumstantial and mainly derived from outside the Convention Area, CCAMLR needed at least to consider precautionary action in fisheries under its jurisdiction to avoid exacerbating the situation.

After further discussion in 1992, CCAMLR convened in 1993 a meeting of relevant experts on seabirds and longline fishing to provide advice to the Scientific Committee. In the meantime, on a precautionary basis, a Conservation Measure (a mandatory, legally-binding provision) was adopted in 1991 and revised in 1992 that restricted longline fishing to night-time, prohibited offal discharge during setting and required a streamer line to be deployed to hinder access by birds to the fishing line.

The meeting of experts advised the Scientific Committee, in essence and inter alia, that:

(a) without reliable bycatch data, the magnitude of the problem could not be assessed;

(b) parties with responsibilities for vessels fishing in the Convention Area had an obligation to provide these data to CCAMLR;

(c) several potentially useful measures to reduce seabird bycatch did exist;

(d) without bycatch data and better information on bycatch circumstances, implementation of effective mitigation measures based on (limited) experience in other fisheries would be difficult;

(e) introduction of mitigation measures would greatly rely on cooperation of fishers and fishing masters and that the reasons for these measures would need explaining in simple terms in appropriate languages;

(f) continuing advice from an expert group would be needed, at least until the problem had been solved.

CCAMLR acknowledged these recommendations and:

(a) created a Working Group (ad hoc but meeting annually from 1994 to the present) on Incidental Mortality Associated with Longline Fishing (later Incidental Mortality Associated with Fishing (IMAF) when bycatch problems in trawl fisheries became evident). This met simultaneously and in close association with the Working Group on Fish Stock Assessment to ensure that all recommendations were endorsed by both groups;

(b) required, from 1993, the presence of international (i.e. not nationals of the flag state of the vessel) scientific observers on each longline vessel fishing in the Convention area, whose duties included reporting on seabird bycatch;

(c) provided booklets, leaflets and posters in all four CCAMLR official languages for all agencies and vessels fishing in the Convention Area (e.g. CCAMLR 1995);

(d) started to develop a suite of mitigation measures to reduce seabird bycatch suitable for application on longline vessels in the Convention Area, comprising elements intended to:

(i) avoid attracting birds by prohibiting ( or limiting) offal discharge;

(ii) scare birds away from the sinking longline by using streamer (tori) lines; 
Table 3. Catch levels and rates of albatrosses by tuna longline fishing vessels off Tasmania in 1988 (from Brothers 1991).

\begin{tabular}{lccl}
\hline Voyage & $\begin{array}{l}\text { Number of hooks } \\
\text { observed }\end{array}$ & $\begin{array}{l}\text { Number of albatrosses } \\
\text { caught }\end{array}$ & $\begin{array}{l}\text { Catch rate per 1,000 } \\
\text { hooks }\end{array}$ \\
\hline A & 32,484 & 12 & 0.37 \\
B & 5,677 & 11 & 1.94 \\
C & 5,326 & 12 & 0.94 \\
D & 40,140 & 0 & 0.30 \\
E & 12,015 & 2 & 0 \\
F & 10,140 & 3 & 0.20 \\
G & 2,880 & 45 & 1.04 \\
Totals & 108,662 & 6.4 & 0.41 \\
Mean & & & \\
\hline
\end{tabular}

(iii) sink the longlines too fast for birds to access (dive for) bait, using heavier and more frequent weights;

(iv) avoid catching albatrosses by setting lines only at night;

(v) fish preferentially in winter when the albatrosses and petrels have migrated out of the Convention Area and are, therefore, at reduced risk.

A more comprehensive summary of the progressive development of measures by CCAMLR to address seabird bycatch and related issues is set out in Table 4 .

\section{Initial outcomes}

Bycatch reduction

It took three years to acquire any reliable bycatch data and four years to obtain sufficient data to enable a reliable (minimum) estimate of mortality of albatrosses and petrels in the South Georgia and Indian Ocean longline fisheries (Table 5). These estimates, of 5,755 and 834 birds killed, respectively, galvanised CCAMLR Members into further action and particularly in terms of mandatory implementation of the mitigation measures set out in section (d) above. The immediate result of this was a reduction in seabird bycatch at South Georgia by one order of magnitude within one year and, as fishing managers, fishing masters, fishers and scientific observers learnt to work together, a further reduction, to less than $1 \%$ of the original estimate, was achieved two years later. In the Indian Ocean, where seasonal closures were not implemented (and operational activity somewhat less integrated), equivalent reductions took another four years.

\section{Improvements in mitigation}

Improvements in the use and management of the technical mitigation measures, linked to progressive incorporation of improvements to these (particularly through line weighting and streamer lines) were responsible for much of the progressive reduction in bycatch.

Indeed, years of minor increases in bycatches (e.g. 2004; see Table 5) could be clearly associated with a drop in the standard of implementation of the technical mitigation measures (CCAMLR 2004).

Even the recent massive bycatches of White-chinned Petrels Procellaria aequinoctialis (about 25,000 birds over years 2002 and 2003 combined) in French-managed fisheries in the Indian Ocean proved susceptible to implementation of the technical mitigation measures used elsewhere, reducing by-catch by $75 \%$ in one season (2004). Clearly streamer lines, line weighting and associated best practice with discharge of offal can produce major improvements in bycatch quite independently of those achieved by closing areas to fishing during the breeding season of seabirds. 
Table 4. Milestones in the development of effective mitigation measures to prevent seabird bycatch in longline fisheries in the CCAMLR Convention Area (from Croxall et al. 2007).

\begin{tabular}{|c|c|c|}
\hline 1. & 1982 & CCAMLR Convention comes into force. \\
\hline 2. & 1986 & Reports of incidental mortality required. \\
\hline 3. & 1989 & $\begin{array}{l}\text { Longline fishing for Patagonian Toothfish starts (around South Georgia); incidental } \\
\text { mortality becomes a CCAMLR agenda item. }\end{array}$ \\
\hline 4. & 1990 & $\begin{array}{l}\text { First unofficial report of seabird by-catch; reporting forms on incidental mortality data } \\
\text { and formats agreed as part of a Conservation Measure. }\end{array}$ \\
\hline 5 . & 1991 & $\begin{array}{l}\text { First direct observations of seabird by-catch; first Conservation Measure on mitigation of } \\
\text { incidental mortality of seabirds. }\end{array}$ \\
\hline 6. & 1993 & $\begin{array}{l}\text { Working Group on Incidental Mortality Associated with Longline Fishing established } \\
\text { (first meeting in 1994). }\end{array}$ \\
\hline 7 . & 1993 & $\begin{array}{l}\text { International scientific observers required on all (four) vessels longline fishing in the } \\
\text { South Georgia area. }\end{array}$ \\
\hline 8. & 1994 & First outreach materials to fishers and fishery managers and approaches to other RFMOs. \\
\hline 9. & 1995 & $\begin{array}{l}\text { Closed season for longline fishing for toothfish ( } 1 \text { August to end February) to assist } \\
\text { reducing incidental mortality of seabirds. }\end{array}$ \\
\hline 10. & 1996 & $\begin{array}{l}\text { First adequate (though incomplete) scientific data (from international scientific observers) } \\
\text { on seabird by-catch (from } 3 \text { of } 16 \text { vessels fishing). }\end{array}$ \\
\hline 11. & 1997 & Highest estimated seabird by-catch $(>6,000$ birds $)$ in regulated fishery. \\
\hline 12. & 1997 & $\begin{array}{l}\text { First comprehensive seabird by-catch risk assessment for different parts of the } \\
\text { Convention Area. }\end{array}$ \\
\hline 13. & 1997 & $\begin{array}{l}\text { Closed fishing season extended by one month (to I April), to protect seabirds until } \\
\text { improved compliance with Conservation Measures. }\end{array}$ \\
\hline 14. & 1998 & Closed fishing season extended by two weeks (to 15 April). \\
\hline 15. & 1999 & $\begin{array}{l}\text { First (autoline) vessels achieve full compliance with all mitigation measures for seabird } \\
\text { by-catch (Conservation Measure 29). }\end{array}$ \\
\hline 16. & 1999 & $\begin{array}{l}\text { Closed fishing season extended to I May to protect seabirds until full compliance with } \\
\text { relevant Conservation Measures. }\end{array}$ \\
\hline 17. & 2001 & $\begin{array}{l}\text { First Spanish-system longline vessel achieves full compliance with all relevant mitigation } \\
\text { measures (Conservation Measure 29). }\end{array}$ \\
\hline 18. & 2002 & $\begin{array}{l}\text { First exemptions to night setting requirements (subject to seabird by-catch limit) for } \\
\text { areas of lower risk for seabird by-catch. }\end{array}$ \\
\hline 19. & 2003 & Seabird by-catch in regulated fishery (except French EEZ) at record low ( 15 birds). \\
\hline 20. & 2003 & $\begin{array}{l}\text { Half of vessels longline fishing comply with relevant mitigation measures for seabird } \\
\text { by-catch (Conservation Measure 25-02 which replaced CM 29). }\end{array}$ \\
\hline 21. & 2003 & $\begin{array}{l}\text { Important revision of mitigation measure requirements (Conservation Measure 25-02), } \\
\text { incorporating use of integrated weight longline; additional exemptions agreed, subject to } \\
\text { seabird by-catch level limits. }\end{array}$ \\
\hline 22. & 2004 & $\begin{array}{l}\text { Seabird by-catch levels in French EEZ reduced by } 75 \% \text { following implementation of } \\
\text { CCAMLR recommendations. }\end{array}$ \\
\hline 23. & 2004 & $\begin{array}{l}\text { Unified system (for whole Convention Area) of mitigation requirements in relation to } \\
\text { seabird by-catch risk. }\end{array}$ \\
\hline
\end{tabular}

\section{Precautionary approaches}

In CCAMLR fisheries already under operation, it was difficult to enact new conservation and management measures before achieving quite a high level of proof of their need (though there was general acceptance of the need to collect enough data to enable this to happen).

Widespread recognition of this situation within CCAMLR led to the distinction between Existing and New and Exploratory fisheries. The latter were subject to much more stringent rules, incorporating several precautionary approaches. An important element of these involved seabird bycatch, whereby each of the FAO divisions and subdivisions of the CCAMLR area were assessed on the basis of risk of interaction between the fishing vessels and albatrosses and petrels susceptible to capture by such fisheries. 
Table 5. Total estimated seabird by-catch and by-catch rate (birds per thousand hooks) in longline fisheries for toothfish Dissostichus spp. in the CCAMLR Convention Area (from CCAMLR 2006).

\begin{tabular}{|c|c|c|c|c|c|c|c|c|c|c|}
\hline \multirow[t]{2}{*}{ Subarea } & \multicolumn{10}{|l|}{ Year } \\
\hline & 1997 & 1998 & 1999 & 2000 & 2001 & 2002 & 2003 & 2004 & 2005 & 2006 \\
\hline \multicolumn{11}{|l|}{$\begin{array}{l}\text { South Georgia } \\
\text { (Subarea } 48.3 \text { ) }\end{array}$} \\
\hline $\begin{array}{l}\text { Estimated } \\
\text { by-catch }\end{array}$ & 5,755 & 640 & 210 & 21 & 30 & 27 & 8 & 27 & 13 & $\mathrm{o}$ \\
\hline By-catch rate & 0.23 & $3 \quad 0.032$ & 0.013 & 0.002 & 0.002 & 0.0015 & 0.0003 & 0.0015 & 0.0011 & o \\
\hline \multicolumn{11}{|l|}{$\begin{array}{l}\text { Indian Ocean } \\
\text { (Subarea } 58.6, \\
58.7 \text { ) }\end{array}$} \\
\hline $\begin{array}{l}\text { Estimated } \\
\text { by-catch }\end{array}$ & 834 & 528 & 156 & 516 & 199 & $\mathrm{o}$ & 7 & 39 & 76 & $\mathrm{o}$ \\
\hline By-catch rate & 0.52 & 0.194 & 0.034 & 0.046 & 0.018 & $\mathrm{o}$ & 0.003 & 0.025 & 0.149 & $\mathrm{o}$ \\
\hline \multicolumn{11}{|l|}{$\begin{array}{l}\text { Ross Sea } \\
\text { (Subarea 88.1, } \\
88.2 \text { ) }\end{array}$} \\
\hline $\begin{array}{l}\text { Estimated } \\
\text { by-catch }\end{array}$ & - & o & $\mathrm{o}$ & o & $\mathrm{o}$ & o & o & 1 & o & $\mathrm{o}$ \\
\hline By-catch rate & - & o & $\mathrm{o}$ & o & $\mathrm{o}$ & $\mathrm{o}$ & o & 0.0001 & $\mathrm{o}$ & $\mathrm{o}$ \\
\hline
\end{tabular}

The risk assessment process, whose current assessments are illustrated in Fig. 2, has become increasing sophisticated in the data inputs and in its integration into the annual review of data and development of management responses by CCAMLR. This process is described in detail in Waugh et al. (2008) and is illustrated in Fig. 3.

Overall, management of seabird bycatch in CCAMLR's new and exploratory fisheries (e.g. starting longline fishing in a new statistical sub-area or division) has been exemplary in terms of adopting a precautionary approach, particularly in defining bycatch risk levels and attendant area-specific mitigation requirements and management actions (see CCAMLR 2004, Table 7.17). So far all regulations have been strictly observed with no, or almost no, seabird bycatch whatsoever. Furthermore, regulated relaxation of mitigation requirements (subject to seabird bycatch limits) have also been entirely successful at avoiding bycatch.

\section{Adaptive management}

Mechanisms for the stepwise removal of some mitigation requirements (e.g. closed seasons), consequent on complete compliance with the necessary mitigation measures, have been agreed and implementation has either commenced and/or the preconditions met. However, greater relaxation of these regulations (e.g. allowing longline fisheries to operate with technical measures alone in the highest risk bycatch areas during the main seabird breeding season), may prove to be quite challenging, especially for avoiding by-catch of White-chinned Petrels and for operations involving the 'Spanish system' (i.e. not using autolines) of longline fishing.

\section{Improved methods for fishers}

Development of new methods which are easier and more effective for fishers to use (e.g. longlines with integrated weight (Robertson et al. 2006) and standardised, streamlined weights (CCAMLR 2006)) are enabling vessels to fish with greater freedom and efficiency than hitherto. Both these gear developments, pioneered by CCAMLR and scientists contributing to IMAF, have potentially far-reaching implications. This is because, by simplifying fishing, as well as 


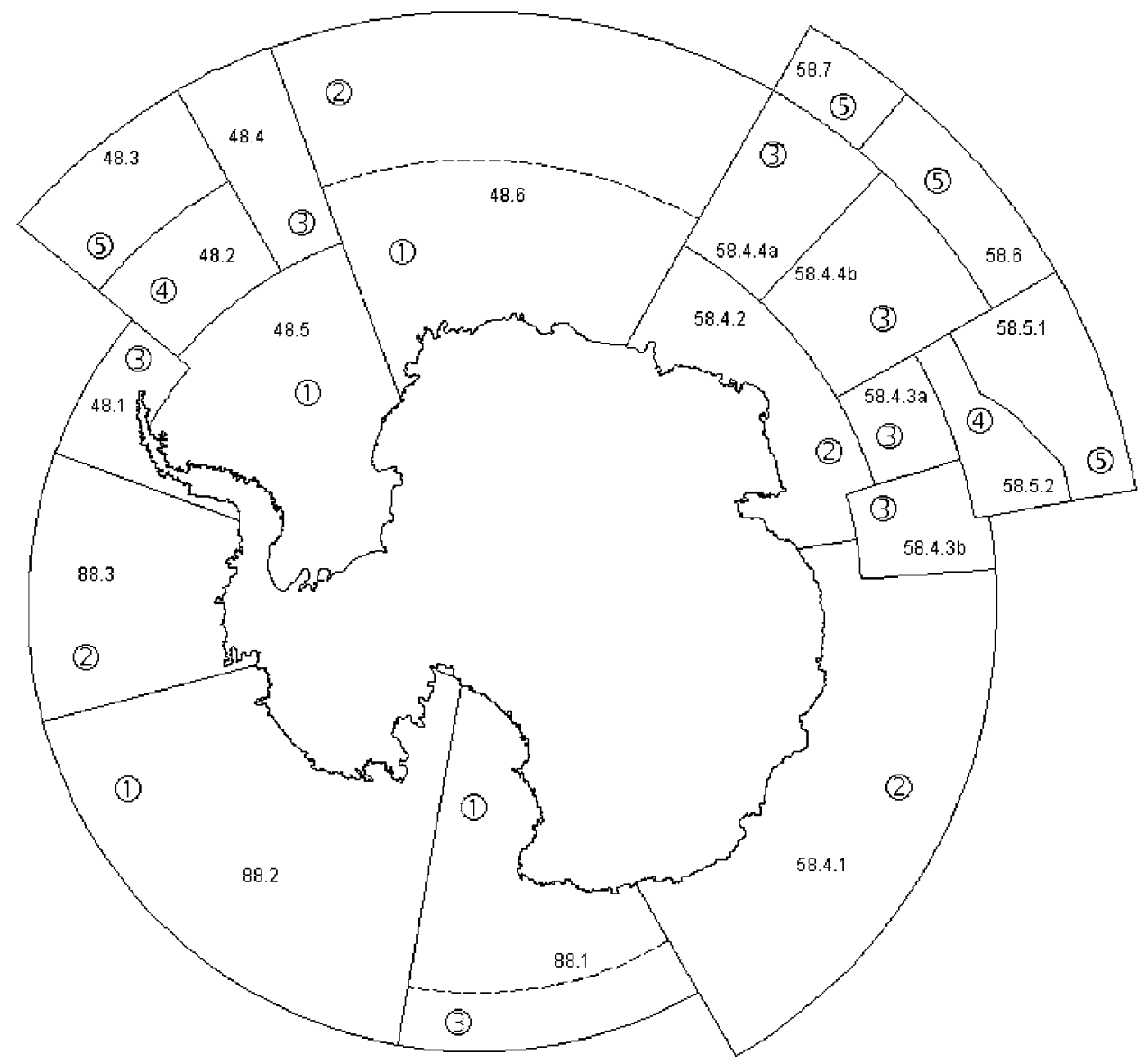

Figure 2. Map of the CCAMLR Convention Area, showing its subdivision into statistical areas and the assessment of each of these for potential risk of interaction between seabirds, especially albatrosses, and longline fisheries. Key: 1 : low; 2: medium to low; 3: average; 4: average to low; 5: high. (From CCAMLR 2006).

reducing seabird bycatch, they are used by fishers in areas where they may not necessarily be compulsory under fishing regulations or where no such regulations exist.

\section{Discussion}

The process described above illustrates that even something as intrinsically difficult as reducing to negligible proportions (in terms of impact on populations concerned), fisheries-related bycatch of a non-target marine vertebrate in a management regime with 24 national stakeholders can be feasible. Nevertheless, it took a decade to achieve this, not least because any CCAMLR mandatory conservation measure requires complete consensus of the 24 Members and fishery interests are traditionally conservative in accepting change. A multitude of national interests and perspectives also complicated matters considerably.

It is important, therefore, to understand some of the main positive and negative influences in the CCAMLR process, in order to assess how feasible it is to apply - or modify- in other analogous circumstances. 


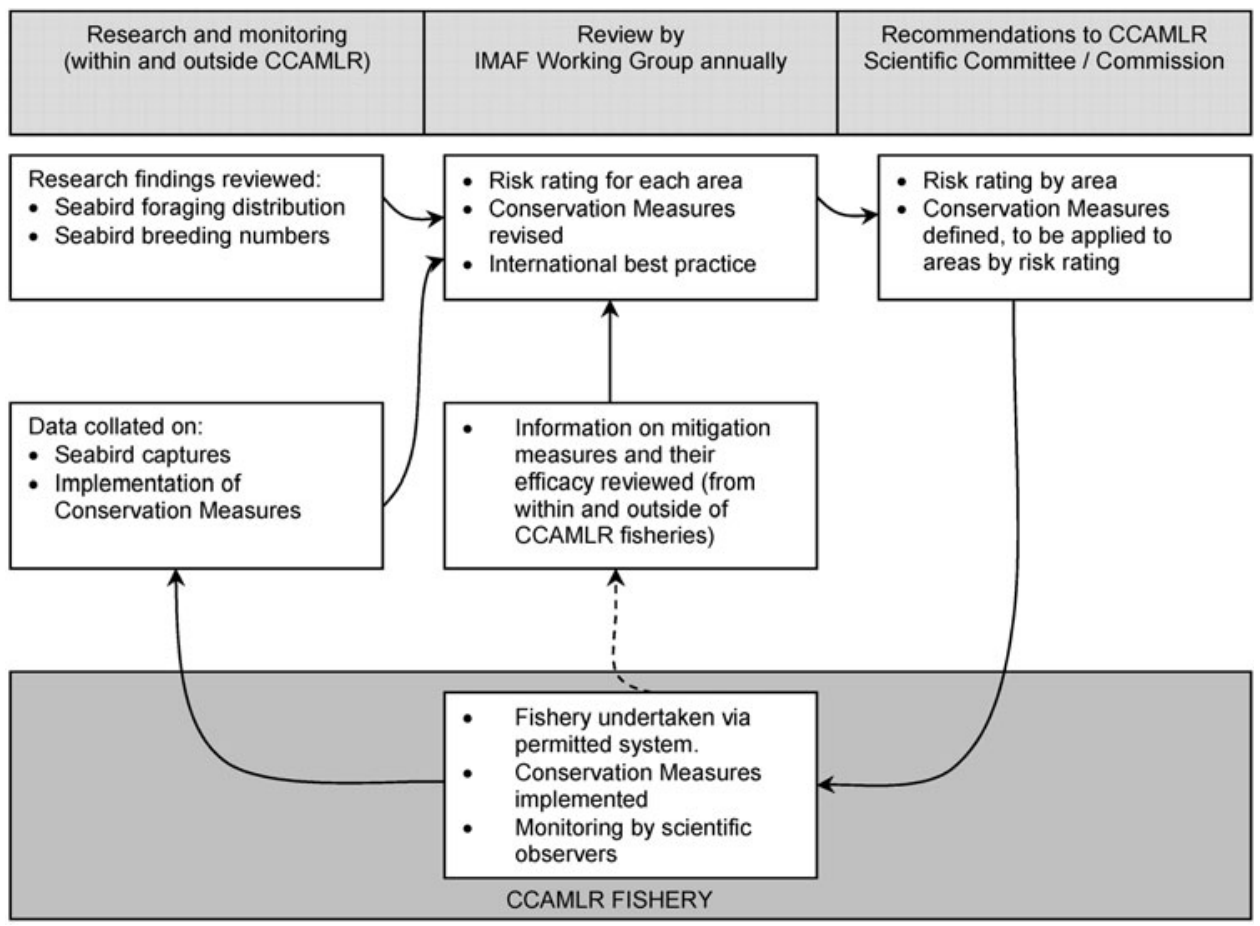

Figure 3. Schematic representation of the application (and context) of the CCAMLR Seabird Risk Assessment (from Waugh et al. 2008).

\section{Positive influences and circumstances}

Fishery-specific issues

1. The fishery for Patagonian Toothfish is high value, so that the initial introduction (and ensuing development) of mitigation measures was not disproportionately costly and, therefore, no disincentive to continued participation in the fishery.

2. The fishery was well-managed in terms of a very conservative total allowed catch, which permitted relatively few vessels to participate and favoured individual vessels trying to comply with management measures in order to maintain their access to the fishery.

3. Within the vast area of application of CCAMLR, the toothfish fishery is relatively restricted geographically, especially to deep shelf-slope waters of sub-Antarctic islands and the Antarctic Continent, which simplifies management, especially in relation to coastal states with jurisdiction around sub-Antarctic islands. This allowed compliance with bycatch reduction measures and with reporting requirements to be part of fishery permit conditions in some circumstances. This was a powerful incentive as non-compliant vessels/companies knew they risked being excluded from the fishery in succeeding years.

\section{RFMO research and management issues}

1. Creation of a formal working group which comprised all stakeholder constituencies - fishers, fishery managers, fishery scientists, technical experts, seabird biologists - to analyse and assess data and to provide advice. In CCAMLR, this was IMAF.

2. General acceptance by CCAMLR's Scientific Committee and Commission that consensus recommendations of its multidisciplinary and multinational working groups constituted the best 
scientific data and advice available. The Scientific Committee and especially the Commission, therefore, required compelling evidence to modify the advice they received, though the Commission was sometimes slow to implement the recommendations, often due to reservations of particular Members.

3. Agreement that all longline (later extended to all fin fish) vessels fishing in the Convention Area must have on board an independent scientific observer, whose duties specifically included reporting on implementation of conservation measures. This specifically excluded official reporting on compliance with conservation measures (which was the responsibility of designated CCAMLR inspectors). This offered observers a degree of 'protection', enabling many of them to operate in ways that gave assistance, rather than hindrance, to the fishing operations. The reports of scientific observers, however, invariably contained information indicating levels of compliance with conservation measures, and until CCAMLR established a new Working Group (Standing Committee on Observation and Inspection), these reports were used, retrospectively but effectively, to assess the progress with implementation of mitigation measures in an official way.

4. Collaborative research into practical solutions involving fishing companies and scientists and supported by governments.

5. The explicit requirement of the CCAMLR Convention to take account of dependent and related species, as well as sustainable management of the fishery itself, provides a more balanced framework than enjoyed by many, and especially the older, RFMOs. It ensured that, on the one hand, adverse impacts on non-target species were actually effectively addressed while, on the other hand, protecting fisheries from changes that were potentially disproportionate to the assessments of risk to the environment or other biota. This influenced both the perception of burden of proof (essentially shared by different interest groups) and of the degree of confidence that was required of the data available.

\section{Negative influences and circumstances}

1. Traditional commercial and operational secrecy at the start of a new fishery was evident. Initial reports (from the Soviet Union) disguised the target species (for at least two years from about 1987), misrepresented the age-cohorts fished (for another couple of years) and provided no data on bycatch for nearly a decade. Methods to mitigate seabird bycatch were not used during most of this period, so at least 35,000 seabirds (including 10,000 albatrosses) were unnecessarily killed.

2. Remoteness of the region and consequent difficulties in policing to counter the illegal and unregulated elements of Illegal, Unregulated and Unreported (IUU) fishing (practitioners of which are highly unlikely to use any measures to mitigate seabird bycatch). For many years, the losses of fish and seabirds from the Convention Area due to illegal fishing exceeded those due to regulated fishing. Unregulated fishing was rapidly addressed within the CCAMLR Area by developing regulations for each part of the area (including risk assessments for seabirds and the concomitant specifications and mitigation measures appropriate for the degree of risk). Tackling illegal fishing became a major task for CCAMLR, especially in the face of initial resistance by certain parties, notably Russia, Ukraine and Uruguay. It took many years before any semblance of effective control was achieved, initially primarily in the South Atlantic sector. The continuing intransigence of some CCAMLR Members and legal considerations and difficulties surrounding some of the fishing companies involved, especially those with beneficial owners linked to Spain, are still significant barriers to elimination of IUU fishing from the region.

3. Failure rapidly to develop a simple but compelling economic model to illustrate the impact of catching seabirds in terms of the costs to the fishery of lost bait, of toothfish uncaught because of loss of bait and the extra fuel and other costs needed to support the additional fishing time needed to reach target catch levels. Despite Brothers (1991) estimate of a potential annual saving of $\mathrm{A} \$ 5$ million in the tuna fishery he observed, recognition that mitigation solutions are very 
cheap in relation to revenue forfeited is still slow to be appreciated.

4. Failure to be able to obtain sufficient resources to test scientifically the contribution that each of the different mitigation measures made to overall bycatch reduction. This created subsequent difficulties in proposing best-practice mitigation measures (and combinations thereof) for new areas, new target species, new vessels, etc. In addition, with the 'Spanish system' of longline fishing it is much less easy to devise general simplifications to mitigation measures, in contrast to the integrated weighting of the main line that achieves so much success for autoline vessels and is rapidly becoming the industry standard wherever such vessels fish. It is very difficult to devise comparable improvements to the Spanish system, but the recent suggestion of providing streamlined standardised weights for all such fishers would represent a significant reduction in labour for the fishers and increased efficiency in the deployment and sinking of gear.

5. Using closed seasons as a mitigation measure, despite its effectiveness at reducing local seabird bycatch, risks displacing fishing to other areas where mitigation and management is likely to be much less effective. This is a particularly important consideration for introduction of large-scale closed seasons/areas, as recommended by some proponents of Marine Protected Areas for the high seas.

\section{Application of the CCAMLR experience}

\section{General}

Overall, the experiences relating to addressing seabird bycatch within the fisheries management system of CCAMLR enables some important lessons to be learned, which are doubtless applicable to many analogous situations in other fishery management contexts.

First, all relevant stakeholders need to be able to work together, on an equal footing, preferably in an appropriate expert group, to consider the relevant data and to develop proposals for appropriate management actions.

Second, such a system or forum needs to accept that management action should, in essence, be proportionate to the severity of the threat or problem and take account of the quality and certainty of the data available and the level of confidence in the interpretation thereof. This should preclude absence of comprehensive scientific information (invariably impossible to achieve) and of certainty in its interpretation being used as an excuse to delay (sometimes indefinitely) any management action other than voluntary ones. Conversely, the degree of confidence in the data (in relation to the perceived severity of the threat) should influence the magnitude (and especially economic consequences) of proposed management actions. It should be noted, however, that the data needed to achieve substantial changes in fishery policy and practice need not either be comprehensive or sophisticated; they do, however, need to be the best available (including taking account of the difficulty in terms of time and resource in obtaining more authoritative information).

Third, in a system where the above principles are accepted, the interactions between research plans, data collection and analysis, policy advocacy and implementation of management decisions should be seen as a stepwise and evolutionary process with appropriate feedback loops.

All this should be self-evident in circumstances, like with most fisheries' bycatch, where the interests of cost-effective fishing and conservation of non-target species coincide, but is even more relevant in circumstances which may be more one-sided.

\section{CCAMLR}

For CCAMLR, in relation to seabird bycatch, most of the essential work to deliver benefits achievable within the Convention Area has now been undertaken. Most bycatch of Convention Area seabirds occurs in adjacent regions and the priority next steps for CCAMLR, as listed in Croxall et al. (2007), include: 
1. Collaborate with adjacent Regional Fishery Management Organisations (RFMOs), especially Indian Ocean Tuna Commission, International Convention for the Conservation of Atlantic Tuna, Commission for the Conservation of Southern Bluefin Tuna and the new Indian Ocean RFMOs, to ensure that seabird bycatch (especially of birds breeding in the Convention Area) is eliminated or minimised by the use of a suite of measures similar to those employed by CCAMLR.

2. Work with relevant CCAMLR members to ensure that their vessels operating in high seas areas adjacent to the Convention Area are employing mitigation measures as effective as those required within the Convention Area.

3. For states into whose waters CCAMLR seabirds migrate (especially Argentina, Australia, Chile, New Zealand and South Africa), ensure that domestic legislation with respect to mitigation is as effective as that required by CCAMLR.

4. Work with relevant CCAMLR members to ensure that successful mitigation by their vessels of seabird bycatch in the CCAMLR area is complemented by equally successful mitigation by these and other vessels in their domestic fisheries (and, indeed, wherever their vessels participate in fisheries where there are risks of seabird bycatch).

This emphasises the need for coastal states and RFMOs in other high seas areas to substantially improve their mechanisms (and the effective implementation of existing mechanisms) for addressing fishery bycatch issues in general.

Many aspects of the CCAMLR model and experiences are highly relevant to this and the development of appropriate expert advisory groups, whether in-country or by RFMOs, together with effective implementation of their advice as a particular priority, could well be guided by the CCAMLR experience.

\section{BirdLife International}

The approaches to seabird bycatch taken by CCAMLR, particularly the establishment of an expert group, the risk assessment process and the pragmatic development and implementation of mitigation measures, were all closely observed by BirdLife International, especially when it decided that a primary task of its new (in1997) Global Seabird Programme would be to address the conservation issues of Southern Ocean albatrosses and petrels. In developing a strategy to address these issues, BirdLife sought to engage at two main levels: a) working with the most relevant fisheries organisations to improve management of bycatch; and b) working with fishers to identify and implement the most appropriate (and cost-effective) methods of reducing seabird bycatch in specific types of fishery.

BirdLife reviewed the existing performance of RFMOs in relation to seabird bycatch and to their obligations under the United Nations Code of Conduct for Responsible Fishing and concluded that, except for CCAMLR, almost no effective action had been taken by any RFMO (Small 2005). Since then, through external advocacy and working with the various scientific advisory groups of each RFMO, BirdLife has contributed to: a) activating or developing working groups to advise RFMOs on bycatch and ecosystem issues (e.g. IOTC 2005, WCPFC 2005, ICCAT 2005); b) defining the spatial and temporal overlap between fisheries and seabirds (BirdLife International 2006a,b,c; 2007a), notably through use of the burgeoning data from satellite-tracking studies (BirdLife International 2004); c) undertaking a formal risk assessment in relation to bycatch of seabirds in the Atlantic Ocean (Phillips et al. 2007a,b); and d) developing and starting to implement advice on best-practice mitigation methods for specific fisheries and areas (e.g. IOTC 2006 WCPFC 2006), including leading the forthcoming FAO expert consultation review for longline and trawl fisheries (FAO 2007).

At the more practical level, BirdLife has collaborated in initiatives to develop new fishing gear which would both reduce bycatch and be easier and more cost-effective to operate (e.g. integrated weight longline for autoliners (Robertson et al. 2006a), hydrodynamic weights for 'Spanish system' vessels [Robertson et al. 2006b]). There is a range of other projects under development, particularly focused on the development of improved mitigation measures for longline fisheries 
(see Melvin and Baker 2006), including collaborating with engineers to develop a new lineweighting system for pelagic gear (BirdLife International 2007b). In 2006 BirdLife established the Albatross Task Force, an international team of bycatch mitigation instructors, to work with fishers and fishery managers ashore and at sea in global seabird bycatch hotspots. In 2006 twoperson teams operated in Brazil and South Africa. In 2007 additional teams (of up to three instructors) were deployed in Argentina, Chile, Namibia and Uruguay. If resources allow, it is planned to expand existing teams and work in other countries, like Ecuador and Peru (BirdLife International 2008). In the longer term the aim is to establish teams to work with Asian fishers but this is unfortunately impracticable at present. Overall, BirdLife is in essence trying to adapt the CCAMLR approach to the often very different circumstances of other RFMOs and to complement this by providing practical help in implementing environmentally friendly fishing. The greatest challenge is exporting both concepts into RFMOs and fisheries dominated by the Asian distant water fleets.

Despite these positive developments, the willingness and ability of most RFMOs to address their obligations in respect of bycaught and dependent species is still profoundly uncertain. Thus it was a major disappointment that the first ever meeting of the five Tuna Commissions in January 2007 could neither agree that addressing bycatch issues was one of their top five priorities nor to participate in the establishment of an externally funded (but managed by the Tuna Commissions) expert working group to address bycatch issues of relevance to all the collaborating RFMOs. The economy and efficiency of such an initiative seems beyond dispute and it can only be hoped that the reality of this will rapidly become apparent to the governments and economic integration organisations that are currently supporting the existing operations of these RFMOs. Many of the same governments and organisations also have decisive roles to play in improving the management of their domestic fisheries in terms of their impact on the environment in general and on non-target species in particular.

\section{Acknowledgements}

I thank all those who worked on these issues in CCAMLR expert groups over the last 15 years and many others who contributed to trying to extend the CCAMLR achievements to a wider stage. Ben Sullivan, Cleo Small and two referees provided numerous helpful suggestions.

\section{References}

Arnold, J. M., Brault, S. and Croxall, J. P. (2006) Albatross populations in peril? A population trajectory for black-browed albatrosses at South Georgia. Ecol. Appl. 16: 419-432.

BirdLife International (2004) Tracking ocean wanderers: the global distribution of albatrosses and petrels. Cambridge, UK: BirdLife International.

BirdLife International (2006a) Distribution of albatrosses and petrels in the Atlantic Ocean and overlap with ICCAT longline fisheries. Collected Volume of Scientific Papers, ICCAT 59(3): 1003-1013.

BirdLife International (2006b) Analysis of albatross and petrel distribution within the IATTC area: results from the Global
Procellariiform Tracking Database. Paper prepared for the Prepared for the Seventh meeting of the IATTC Working Group to Review Stock Assessments, La Jolla, California, 15-19 May 2006. Doc SAR-7o5b.

BirdLife International (2006c) Distribution of albatrosses and petrels in the WCPFC Convention Area and overlap with WCPFC longline fishing effort. Paper submitted to the Second Regular Session of the WCPFC Scientific Committee, 7-18 August 2006, Manila, Philippines.

BirdLife International (2007a) Analysis of albatross and petrel distribution and overlap with longline fishing effort within the 
IOTC area: results from the Global Procellariiform Tracking database. Paper submitted to the Third Session of the IOTC Working Party on Ecosystems and Bycatch, Seychelles, 2007. IOTC-2007-WPEB-22.

BirdLife International (2007b) Smart leads. Sea Change Newsletter, Issue 3. Cambridge, UK: BirdLife International.

BirdLife International (2008) The Albatross Task Force: progress and challenges 2006/ 07 and beyond Cambridge. UK: Report of the Global Seabird Programme.

Brothers, N. (1991) Albatross mortality and associated bait loss in the Japanese longline fishery in the Southern Ocean. Biol. Conserv. 55: 255-268.

Brothers, G., Gales, R. and Reid, T. (1998) Seabird interactions with longline fishing in the AFZ: 1996 seabird mortality estimates and 1988-1996 trends. Wildlife Report 98/1. Hobart, Tasmania: Parks and Wildlife Service.

CCAMLR (1995) Fish the sea not the sky: how to avoid by-catch of seabirds when fishing with bottom longlines. Hobart: CCAMLR.

CCAMLR (2004) Report of the twenty-third meeting of the Scientific Committee. Hobart, Australia: CCAMLR.

CCAMLR (2006) Report of the twenty-fifth meeting of the Scientific Committee. Hobart, Australia: CCAMLR.

Croxall, J. P. and Nicol, S. (2004) Management of Southern Ocean resources: global forces and future sustainability. Antarct. Sci. 16: 569-584.

Croxall, J. P. and Prince, P. A. (1990) Recoveries of wandering albatrosses Diomedea exulans ringed at South Georgia 1958-1986. Ringing Migr. 11: 43-51.

Croxall, J. P. and Rothery, P. (1991) Population regulation of seabirds: implications of their demography for conservation. Pp. $272-296$ in C. M. Perrins, J. D. LeBreton and G. M. Hirons, eds. Bird population studies: relevance to conservation and management. Oxford: Oxford University Press.

Croxall, J. P., Prince, P. A., Rothery, P. and Wood, A. G. (1998) Population changes in albatrosses at South Georgia. Pp. 68-83 in G. Robertson and R. Gales, eds. Albatross biology and conservation. Chipping Norton, Australia: Surrey Beatty \& Sons.

Croxall, J. P., Rivera, K. and Moreno, C. A. (2007) Seabird bycatch mitigation: the Southern Ocean (CCAMLR) experience. Chapter 8, Working with fisheries to reduce bycatches, Case Study 7 . Pp. 271-281 in S. J. Kennelly, ed. Bycatch reduction in the world's fisheries. Berlin: Springer-Verlag.

Croxall, J. P., Rothery, P., Pickering, S. P. C. and Prince, P. A. (1990) Reproductive performance, recruitment and survival of wandering albatrosses Diomedea exulans at Bird Island, South Georgia. J. Anim. Ecol. 59: 775-796.

Dalziell, J. and de Poorter, M. (1993) Seabird mortality in longline fisheries around South Georgia. Polar Rec. 29: 143-145.

Food and Agriculture Organisation (2007) Report of the Twenty-seventh Meeting of the Committee on Fisheries (COFI), March 5-9, Rome, Italy. FAO Fisheries Report 230. ICCAT (2005) 2005 Report of the SubCommittee on Bycatch, 5 October 2005, Madrid.

IOTC (2005) Report of the First Session of the IOTC Working Party on Bycatch. Phuket, Thailand, 20 July, 2005. IOTC2005-WPBy.

IOTC (2006) Resolution 06/04 On Reducing Incidental Bycatch Of Seabirds In Longline Fisheries.

Jouventin, P. and Weimerskirch, H. (1990) Long-term changes in seabird and seal populations in the Southern Ocean. Pp. 208-213 in K. R. Kerry and G. Hempel, eds. Antarctic ecosystems: Ecological change and conservation. Berlin: Springer-Verlag.

Klaer, N. and Polacheck, T. (1998) The influence of environmental factors and mitigation measures on bycatch rates of seabirds by Japanese longline fishing vessels in the Australian region. Emu 98: 305-316.

Kock, K.-H., Reid, K., Croxall, J. P. and Nicol, S. (2007) Fisheries in the Southern Ocean an ecosystem approach. Phil. Trans. Roy. Soc. Lond 362: 2333-2349.

Melvin, E. and Baker, B., eds. (2006) Summary Report: Seabird Bycatch Mitigation in Pelagic Longline Fisheries 
Workshop, October 14, 2006. Hobart, Tasmania: Museum of Natural History.

Phillips, R. A., Small, C. and Howgate, E. (2007a) Studies of distribution, population dynamics and bycatch rates of seabirds in the Atlantic. Paper submitted to the 2007 Meeting of the ICCAT Sub-Committee on Ecosystems, Madrid, Spain - February 19 to 23, 2007. Doc. CRS/2007/o29/Updated.

Phillips, R. A., Tuck, G. and Small, C. (2007b) Assessment of the impact of ICCAT fisheries on seabirds: proposed methodology and framework for discussion. Paper submitted to the 2007 Meeting of the Sub-Committee on Ecosystems, Madrid, Spain - February 19 to 23, 2007. Doc. SCRS/2007/o3o.

Poncet, S., Robertson, G., Phillips, R. A., Lawton, K., Phalan, B., Trathan, P. N. and Croxall, J. P. (2006) Status and distribution of wandering, black-browed and greyheaded albatrosses breeding at South Georgia. Polar Biol. 29: 772-781.

Prince, P. A., Rothery, P., Croxall, J. P. and Wood, A. G. (1994) Population dynamics of black-browed and grey-headed albatrosses at Bird Island, South Georgia. Ibis 136: 50-75.

Robertson, G., McNeill, M., Smith, N., Wienecke, B., Candy, S. and Olivier, F. (2006a) Fast sinking (integrated weight) longlines reduce mortality of whitechinned petrels (Procellaria aequinoctialis) and sooty shearwaters (Puffinus griseus) in demersal longline fisheries. Biol. Conserv. 132: 458-471.

Robertson, G., Moreno, C. A., Guitierrez, E., Candy, S. G. and Seco Pon, J. -P. (2006b) Line weights of constant mass (and sink rate) for Spanish-rig Patagonian toothfish longline vessels. WG-FSA 07/15,
SC-CCAMLR XXVI, CCAMLR, Hobart, Australia.

Small, C. (2005) Regional Fishery Management Organisations. Their duties and performance in reducing bycatch of albatrosses and other species. Cambridge, UK: BirdLife International.

Tuck, G. S., Polacheck, T., Croxall, J. P. and Weimerskirch, H. (2001) Modelling the impact of fishery by-catches on albatross populations. J. Appl. Ecol. 38: 1182-1196.

Tuck, G. N., Polacheck, T., Croxall, J. P., Weimerskirch, H., Ryan, P., Nel, D., Wayte, S. and Bulman, C. M. (2004) Modelling the impact of fishery incidental mortality on three populations of wandering albatross. Pp. 149-241 in G. N. Tuck, ed. A comprehensive study of the ecological impacts of the worldwide pelagic longline industry: Southern Hemisphere studies. Melbourne: CSIRO.

Waugh, S. M., Baker, G. B., Gales, R. and Croxall, J. P. (2008) CCAMLR process of risk assessment to minimise the effects of longline fishing mortality on seabirds. Marine Policy 32: 442-454.

WCPFC (2005) First meeting of the WCPFC Ecosystem and Bycatch Specialist Working Group, $13^{\text {th }}$ August 2005, Noumea, New Caledonia.

WCPFC (2006) Resolution On The Incidental Catch Of Seabirds. Conservation and Management Measure 2006-02.

Weimerskirch, H., Brothers, N. and Jouventin, P. (1997) Population dynamics of wandering albatross Diomedea exulans and Amsterdam albatross D. amsterdamensis in the Indian Ocean and their relationships with longline fisheries: conservation implications. Biol. Conserv. 75: 257-270.

JOHN P. CROXALL

BirdLife International Global Seabird Programme, Wellbrook Court, Girton Road, Cambridge $\mathrm{CB}_{3} \mathrm{ONA}$, U.K. E-mail: john.croxall@birdlife.org 